Металлофиз. новейшие технол. / Metallofiz. Noveishie Tekhnol. () 2014 ИМФ (Институт металлофизики 2014, т. 36, № 9, сс. 1247-1258

им. Г. В. Курдюмова НАН Украины)

Оттиски доступны непосредственно от издателя

Фотокопирование разрешено только

Напечатано в Украине.

в соответствии с лицензией

PACS numbers: 06.60.Vz, 07.20.Hy, 61.43.Gt, 81.05.Bx, 81.20.Ev, 81.70.Pg

\title{
Thermal Analyses for Induction Sintering of Powder Metal Compacts up to Sintering Temperature
}

\author{
U. Çavdar, E. Atik*, M. B. Akgül*, and H. Karaca** \\ Celal Bayar University, Vocational School, Department of Machinery, \\ Turgutlu Campus, \\ 45400 Manisa, Turkey \\ "Celal Bayar University, Mechanical Engineering Department, \\ Muradiye Campus, \\ Manisa, Turkey \\ *Dokuz Eylül University, \\ Department of Electronic Engineering, \\ Izmir, Turkey
}

Induction sintering is developed as an alternative method to conventional sintering in order to sinter iron-based powder metal (PM) compacts. In this study, the $12 \mathrm{~kW}$ power and $30 \mathrm{kHz}$ frequency induction-sintering machine is used for $3 \mathrm{wt} . \%$ copper-mixed iron. The effects of different shapes and sizes of the induction coil, and temperature differences on the PM compacts up to sintering temperature are investigated; these parameters are determined both theoretically and experimentally during induction sintering. Iron-based $\mathrm{PM}$ compacts are sintered at $1120^{\circ} \mathrm{C}$. Induction sintering of iron-based PM compacts are simulated using a program to examine the effects of magnetic flux and temperature distribution in the sample over time. The results are compared with the experimental studies.

Індукційне спікання було розроблено як альтернатива звичайному спіканню, щоб спікати брикети порошкових матеріялів (ПМ) на основі заліза. В даній роботі використано індукційну агломераційну машину поту-

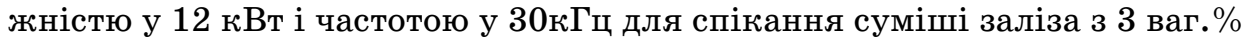
міді. Досліджено впливи різних форм і розмірів індукційної шпулі, ріжниць температур на брикети ПМ аж до температури спікання; ті параметри було досліджено як теоретично, так й експериментально під час індукційного спікання. Брикети ПМ на основі заліза спікалися при $1120^{\circ} \mathrm{C}$. Індукційне спікання брикетів ПМ на основі заліза також модельовано з використанням програми, яка досліджує впливи магнетного потоку та розподілу температури у зразку з часом. Результати порівняно з результатами експериментальних досліджень. 
Индукционное спекание было разработано как альтернатива обычному спеканию, чтобы спекать прессовки порошковых материалов (ПМ) на основе железа. В данной работе использована индукционная агломерационная машина мощностью 12 кВт и частотой 30 кГц для спекания смеси железа с 3 масс.\% меди. Исследованы влияния различных форм и размеров индукционных катушек, разниц температур на брикеты ПМ вплоть до температуры спекания; эти параметры были исследованы как теоретически, так и экспериментально во время индукционного спекания. Брикеты ПМ на основе железа спекались при $1120^{\circ} \mathrm{C}$. Индукционное спекание брикетов ПМ на основе железа также смоделировано с использованием программы, которая исследует влияние магнитного потока и распределения температуры в образце со временем. Результаты сопоставлены с результатами экспериментальных исследований.

Key words: induction, sintering, medium frequency, iron, thermal analysis.

(Received February 2, 2014; in final version, June 6, 2014)

\section{INTRODUCTION}

Generally, powder metal (PM) compacts are sintered using conventional sintering furnaces. The sintering furnace controls heat and time during the sintering loop. In addition, it maintains the required atmosphere and provides the possibility of heat treatment $[1,2]$.

Different PM steels were produced using different methods and different shapes. Salak et al. studied low-carbon steel and distalloy of SA and SE (höganas powders) [3]. They used pressed iron-based PM powders produced by uniaxial cold pressing and sintered by the conventional method at temperatures in the range of $1120-1300^{\circ} \mathrm{C}$ similar to our iron-based PM compacts sintered at $1120^{\circ} \mathrm{C}$ by the conventional method. They tested the machinability of the iron-based PM steels. Cristofolini et al. [4] produced ring-shaped parts with a $\mathrm{Fe}-\mathrm{Cu}-\mathrm{P}$ alloy by a conventional powder metallurgy process. They investigated the effect of anisotropic dimensional change on the precision of PM parts. In this study, despite a slight densification, dimensional changes were anisotropic; in some cases, swelling was observed, whereas shrinkage was observed in others. Raza et al. [5] sintered 316L stainless steel in vacuum by powder injection moulds. Reducing the cooling rate reduced the density, mechanical properties, and corrosion resistance of the $316 \mathrm{~L} \mathrm{PM}$ compacts.

Kurt and Ateş [6] used the ASC 100.26 iron-based composition. They have found that densification is better for the samples sintered at $1150^{\circ} \mathrm{C}$. In addition, Arik and Turker [7] were investigating mechanical alloying of the same composition. They reported that mechanical alloying resulted in the formation of finer powder particles containing homogeneously distributed carbon in iron. They said this process also 
caused the high deformation of particles, which increased the internal energy.

Shon et al. [8] investigated the sintering of TiC without the use of a binder by the high frequency induction heated sintering (HFIHS) method. The aim of their research is to produce dense fine grained binderless $\mathrm{TiC}$ hard material. Consolidation temperature decreased with milling time because driving force for sintering and contact points of powders for atomic diffusion increased. Shon et al. [9] described effect of $\mathrm{Fe}_{2} \mathrm{O}_{3}$ addition on consolidation and properties of 8 mol.\% yttria-stabilized zirconia using high-frequency induction heated sintering.

Watanabe and Kohno [10] reported that the bonding infiltrated skeletons of ion green parts of up to $25 \%$ porosity when infiltration was carried out by C-10Sn bronze at $1150^{\circ} \mathrm{C}$ for 15 minutes in hydrogen followed by furnace cooling. The heating rate was kept at $7^{\circ} \mathrm{C} \cdot \mathrm{min}^{-1}$.

For these HIFIHS studies, they used a $50 \mathrm{kHz}$ induction generator. On the other hand, Çavdar et al. studied iron and iron-based powder metal compacts sintered by a low-medium frequency $(30-50 \mathrm{kHz})$ induction heated system after compacts were pressed coldly [11-14].

Çavdar et al. studied iron and iron-based powder metal compacts for sintering by medium frequency induction sintering [11-14]. Çavdar et al. [11-14] have sintered cold pressed iron-copper compacts via medium frequency induction. These induction sintered compacts have higher density than conventional sintered compacts. Strength and microhardness increased with increased sintering time [11] and increasing copper content up to 3\%. Çavdar's [14] studies show that the best compositions were 3 wt. $\% \mathrm{Cu}$ and 3 wt.\% CuSn15-mixed iron-based PM compacts for the induction sintering process. Çavdar and Atik [14] reported that the optimum sintering temperature of the medium frequency induction heated sintering process of iron-copper PM compacts was $1120^{\circ} \mathrm{C}$ and sintering time was 500 seconds. Therefore, we used same compositions and same induction sintering parameters in this work.

When medium $(30 \mathrm{kHz})$ frequency induction and conventional sintering processes of the iron-based PM compacts energy costs are compared, the induction sintering process is approximately 3.5 times cheaper [15]. The advantage of less consuming energy could be used for the sintering of PM compacts industrially. Çavdar and Atik [15] reported that induction-sintered iron-based compacts are sintered nearly five times quicker than conventional sintered compacts.

In this study, we investigated 3 wt. $\% \mathrm{Cu}$ and iron-based PM compacts sintered by medium frequency induction heated system. The thermal and magnetic analyses of induction-sintered compacts were modelled by the ANSYS program.

The goal of this research is to compare experimental and numerical 
results of sintering temperature of powder metal compacts with medium frequency induction heating method.

\section{MATERIALS AND METHODS}

The sizes of the iron and copper powder were 45-106 $\mu \mathrm{m}$. The powder metal samples sizes were $10 \times 10 \times 55 \mathrm{~mm}^{3}$ and weighed approximately $37 \mathrm{gr}$. Sample compacts were produced by pressing at a pressure of 600 MPa using a uniaxial press. The compacts were sintered by induction sintering furnace

$\mathrm{PM}$ compacts were sintered by $12 \mathrm{~kW}, 30 \mathrm{kHz}$ (medium frequency) in an induction-sintering furnace during 8.33 minutes $(500 \mathrm{~s})$ under atmospheric environment. The temperature of the compacts was measured by infrared thermometer $\left( \pm 5^{\circ} \mathrm{C}\right)$ during the induction sintering process. Compacts were cooled naturally. Çavdar [14] obtained optimum sintering parameters for induction and conventional sintering of the iron-based PM compacts as used in this study.

In the sintering process of the induction, PM compacts were heated rapidly. Due to this rapid heating, some hot spots are seen in the compacts. Hot spots caused rapid delubrication of zinc stearate [15]. This is a common failure in induction sintering [16]. To avoid such failures, a continuous sintering mechanism was developed. Using a moving sample through an induction field, three zones were formed: presintering, sintering, and cooling, producing better delubrication and heat distribution. A horizontal and square coil was designed for the induction sintering process of PM compacts. The induction coil had a diameter of $8 \mathrm{~mm}$ and a wall thickness of $1 \mathrm{~mm}$. The copper wire was wrapped 10 times to make a coil with an inner diameter of $32 \mathrm{~mm}$. The coil was wrapped horizontally as presented in Fig. 1. $30 \mathrm{~mm}$ (outer diameter) quartz tube was used to centre the PM compacts. Homogenous magnetic flux was achieved by centring of the PM compact (Fig. 2).

PM compacts were sequentially pushed forward with a constant rate through the induction field. A ceramic material was used for the pusher rods to avoid its interaction with the magnetic flux. There were three stages during the movement of samples: pre-sintering, sintering, and cooling process. In the pre-sintering zone, zinc-stearate was delubricated without creating hot spots.

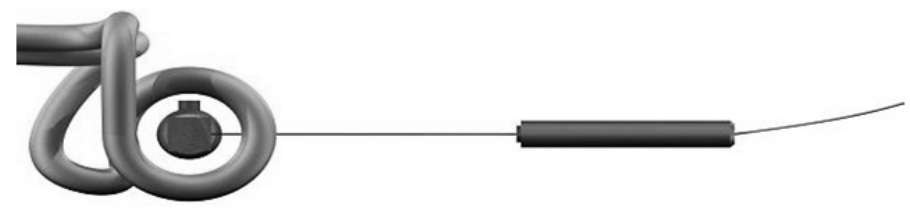

Fig. 1. PM compact and coil design. 

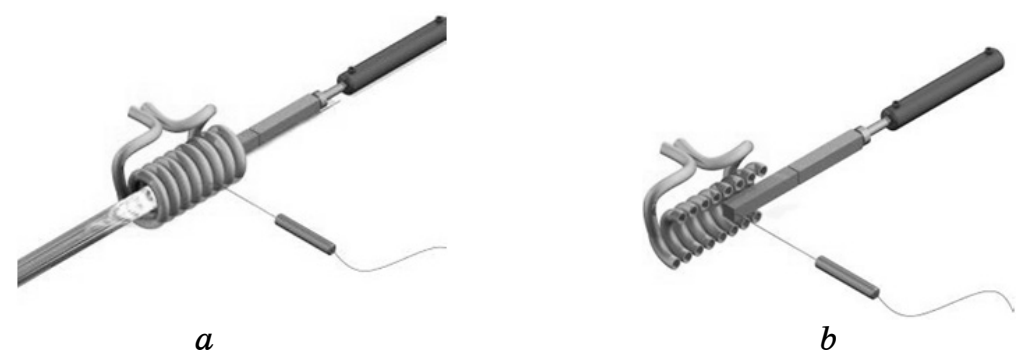

Fig. 2. General aspect of induction sintering mechanism (a) and crosssectional aspect of sintering action showing the samples and pyrometric temperature measurement $(b)$.

The magnetic flux, which interacts with the sample, penetrates to a certain depth. This is defined as the penetration depth in scientific literature [17]. Penetration depth can be formulated as below:

$$
d=5000 \sqrt{\rho / \mu f}[\mathrm{~cm}][17],
$$

where $\rho$ is a specific resistivity, $\mu$ is magnetic permeability and $f$ is frequency.

Specific resistivity $\rho$ of the $\mathrm{Fu}-\mathrm{Cu}$ compact was calculated by designed system, which is given in Fig. 3. This system was designed by Prof. Dr. Haldun Karaca in Electronic Engineering Department of Dokuz Eylül University.

The penetration depth was calculated as $3.3 \mathrm{~mm}$ when we used a fre-

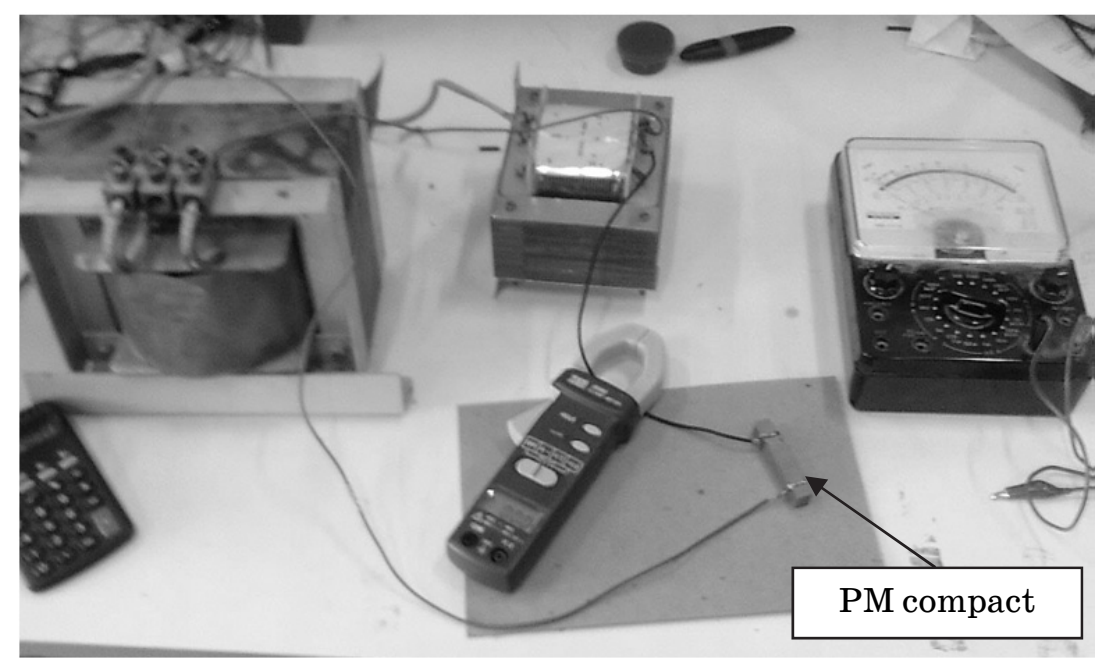

Fig. 3. Measurement of the resistivity of PM compact. 
quency of $30 \mathrm{kHz}$ during the experiments. The penetration depth of magnetic flux is presented in Fig. 4.

Processing parameters of medium frequency heated sintering of PM compacts are presented in Table 1.

The thermal and magnetic analyses of the induction-sintered compacts were modelled by ANSYS program. The relative magnetic permeability of iron-based compacts was reduced to 1 due to a rise in temperature when the sample was heated to the Curie temperature of $769^{\circ} \mathrm{C}$. Above the Curie point, the compact acted non-magnetically. Electrical resistance increased with temperature and slowed down after a certain temperature was reached. The relative magnetic permeability of air and coil was chosen as 1 and the emissivity of iron-based compacts was set to 0.56 during the investigations according to literature [14, 18].

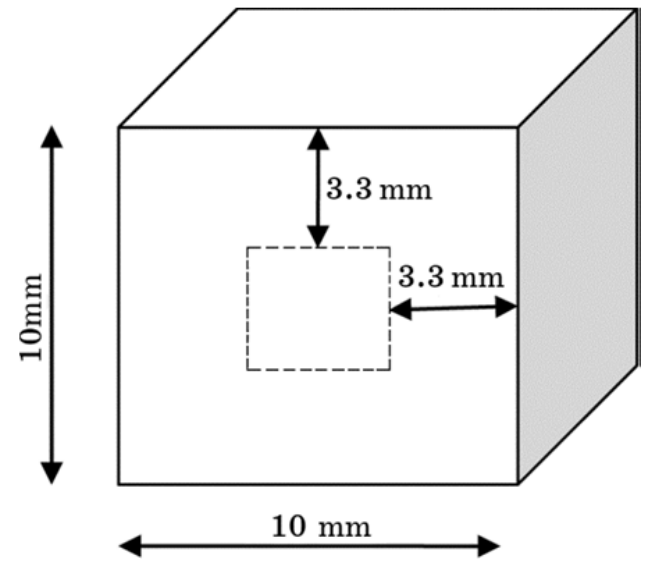

Fig. 4. Penetration depth of magnetic flux in the cross-section of the sample.

TABLE 1. Processing parameters of medium frequency induction heated sintering of PM compacts.

\begin{tabular}{cc}
\hline Parameter & Applied value for induction sintering \\
\hline Maximum Temperature & $1120^{\circ} \mathrm{C}$ \\
Power capacity & $12 \mathrm{~kW}$ \\
Frequency & $30 \mathrm{kHz}$ \\
Pre-sintering time & Unavailable \\
Duration & 8.33 minutes $(500 \mathrm{~s})$ \\
Heating rate & $\cong 75^{\circ} \mathrm{C} / \mathrm{s}$ \\
Cooling rate & Naturally \\
Environment & Atmosphere \\
\hline
\end{tabular}


Magnetic influence has been recognized ' 0 ' for external surfaces of the air. Symmetric boundary condition has been entered for the bottom surface of the sample. Radiation boundary condition has been entered for the other surfaces of the sample.

Plane 13 is generally used for a $2 D$ magnetic, thermal, electrical, and structural field capability with limited coupling between the field applications. This element has nonlinear magnetic capability for modelling B-H curves or permanent magnet demagnetization curves. Because Plane 13 was used for coil, PM compact and air during magnetic flux were analysed by ANSYS. Plane 55 is usually using a plane element or an axisymmetric ring element with a two-dimensional thermal conduction capability. In addition, Surf. 151 is used for various load and surface effect applications. It may be overlaid onto a face of any $2 D$ thermal solid element. The both Plane 55 and Surf. 151 elements are applicable to two-dimensional thermal analyses. Plane 55 is used for thermal analysis of PM compact and Surf. 151 is used for investigation of radiation effect over the sample. To improve the interaction of magnetic flux with the sample, the square was chosen. Coils were wrapped as square and circle and then they used ANSYS analysis. One edge of the square was sectioned coil and inner diameter of circle sectioned coil $32 \mathrm{~mm}$ was chosen and the sample cross-section was set to $10 \times 10 \mathrm{~mm}^{2}$ during ANSYS analysis. The interactions of magnetic flux for both coil design is given in Fig. 5. It was found that magnetic flux is much more congested in the edges of sample for circle-sectioned coil than the square-sectioned coil.

Heat distributions over time during pre-sintering, sintering, and cooling zones are investigated by the thermal analysis method of ANSYS for moving samples. Three consecutive samples were investigated by ANSYS. Half of the cross section of the sample and coil were
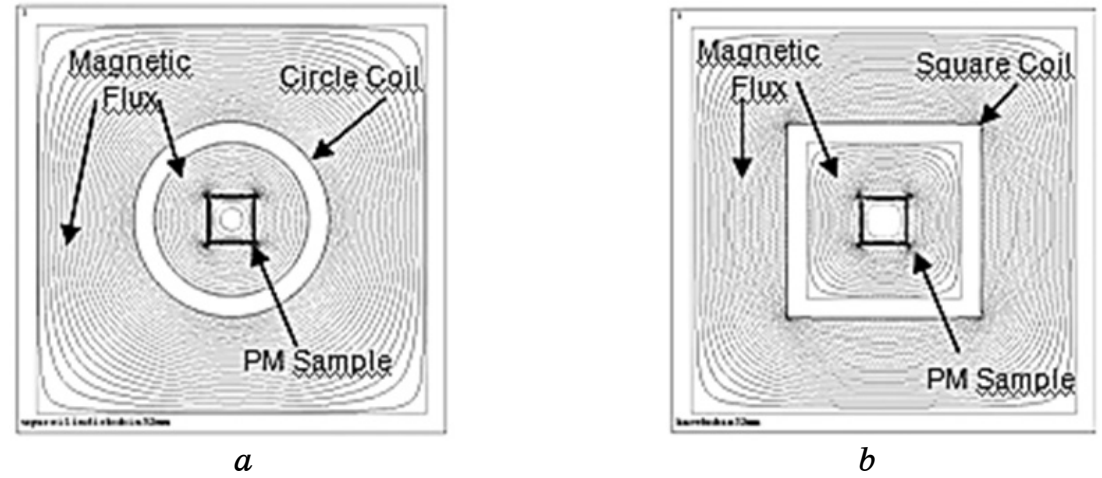

Fig. 5. Magnetic flux interaction with PM sample for square sectioned coil (a) and circle sectioned coil $(b)$. 
modelled during investigations. The samples and the coils were than meshed. The numerical analyses results of the mesh structure are similar to the results obtained from those of an experimental study as shown in Fig. 7. The power of the induction generator is fixed as $\mathbf{1 . 2}$ $\mathrm{kW}$. Air, induction coil, and cross-section of the three compacts were drawn in the discretization analyses (Fig. 6).

\section{RESULTS AND DISCUSSION}

Three consecutive samples were moved with a constant rate through the induction coil during experimental induction sintering studies. The power of the induction generator was set to $1.2 \mathrm{~kW}$. The ANSYS analysis was carried out by heating to the sintering temperature for 1 , $5,10,45$, and 53 seconds as shown in Fig. 7 . It was measured by infrared pyrometer that the sample $\mathrm{PM}$ compact was heated to $1120^{\circ} \mathrm{C}$ in 53 seconds during experimental studies while ANSYS modelling claimed that the sample could be heated to $1120^{\circ} \mathrm{C}$ in 45 seconds.

In modelling, following three PM samples were named S1, S2, and S3, respectively. These three samples are shown in Fig. 6. S1 was presintering, S2 was sintering and S3 was cooling PM compact of the induction sintering process.

The midpoint-centre temperatures of the S2 PM compact for 1-53 seconds sintering time were $116^{\circ} \mathrm{C}$ (for 1 second in Fig. $7, a$ ), $370^{\circ} \mathrm{C}$ (for 5 second in Fig. $7, b$ ), $760^{\circ} \mathrm{C}$ (for 10 second in Fig. $7, c$ ), $1150^{\circ} \mathrm{C}$ (for 45 second in Fig. $7, d$ ) and $1110^{\circ} \mathrm{C}$ (for 53 second in Fig. $7, e$ ) respectively. The midpoint-surface temperature of S2 PM compact for 153 seconds sintering time were $207^{\circ} \mathrm{C}$ (for 1 second in Fig. $7, a$ ), $497^{\circ} \mathrm{C}$ (for 1 second in Fig. $7, b$ ), $805^{\circ} \mathrm{C}$ (for 1 second in Fig. $7, c$ ), $1100^{\circ} \mathrm{C}$ (for

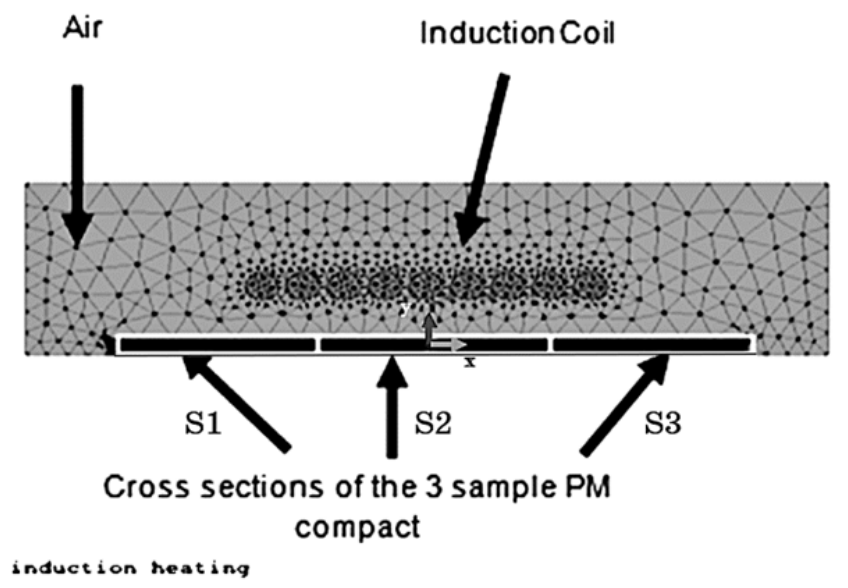

Fig. 6. Aspect of meshing 3 samples following one after another, coil and air. 
1 second in Fig. 7, $d$ ), and $1170^{\circ} \mathrm{C}$ (for 1 second in Fig. 7, $e$ ), respectively. Both centre and surface temperatures of the PM compacts are intercompared in Fig. 8. Centre and surface temperatures were very similar after 10 seconds.

This is one of the advantages of PM compacts sintered with induction. Because of the close temperature range, PM compacts are sintered more homogenously than during convention sintering. This calculation is one of the most important points of this study, because we do not know the inner temperature of the samples while they are heating. Midpoint-surface temperature of S1, S2 and S3 are intercompared in Fig. 9. S1 (pre-sintering) and S3 (cooling) surface temperatures are completely same as the real temperatures of the induction sintering processes, but S3 surface temperatures are not. The curves of S1 and S3 are overlapped. Because of this, the curve of S3 is not seen in the Fig. 9. In the cooling operation, PM compacts are cooled naturally.

While comparing surface temperatures of the ANSYS analyses and real process, the error ranges of the analysis is $\pm 5 \%$. Only the cooling operations were not calculated by ANSYS analysis in the induction sin-
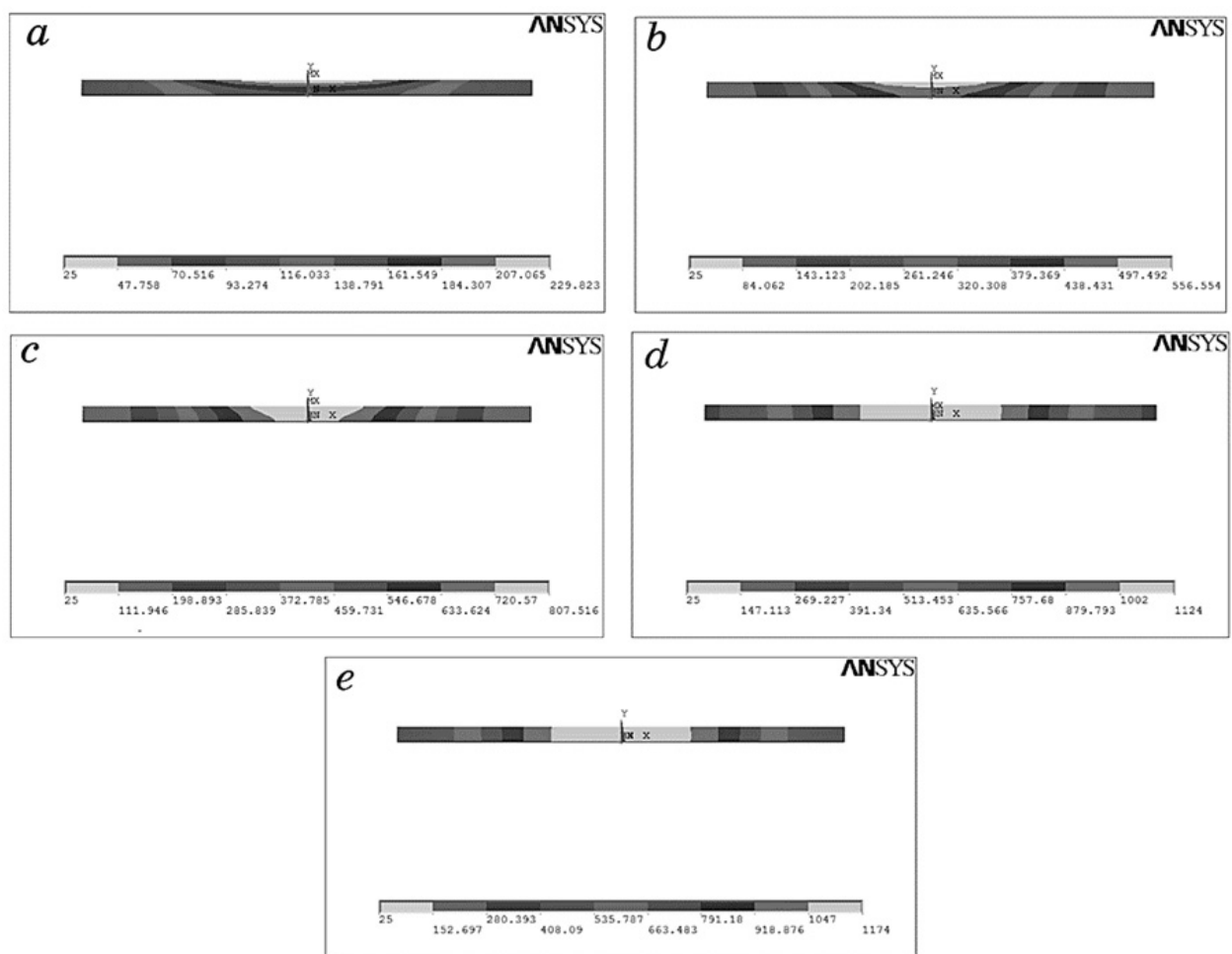

Fig. 7. Heat distribution in the sample during induction sintering in $1 \mathrm{~s}(a), 5 \mathrm{~s}$ $(b), 10 \mathrm{~s}(c), 45 \mathrm{~s}(d)$ and $53 \mathrm{~s}(e)$. 
tering process.

PM compacts were heated together with magnetic fields and convention transfer. Çavdar et al. [14] reported that in the induction sintering process magnetic fields passed through nearly $300 \mu \mathrm{m}$ from interior and exterior surface of the PM bushing compacts. Because of these magnetic fields, almost $600 \mu \mathrm{m}$ of the PM bushing compacts crosssection were heated for the same time. This resulted in quicker heating and sintering of the PM compacts.

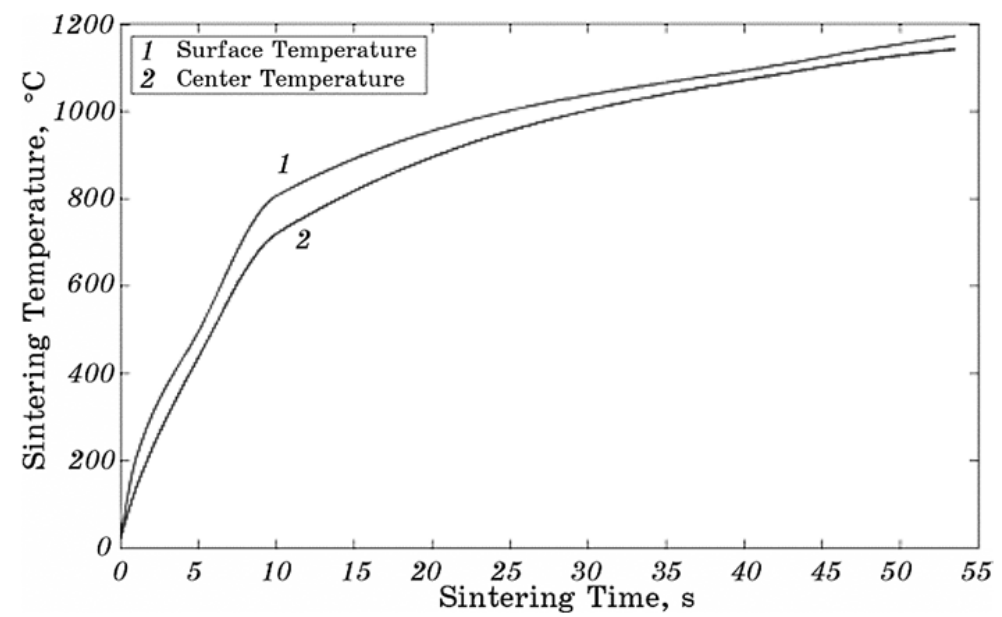

Fig. 8. Variation of sintering temperature with sintering time of surface and centre temperature of iron-based PM compacts in ANSYS modelling.

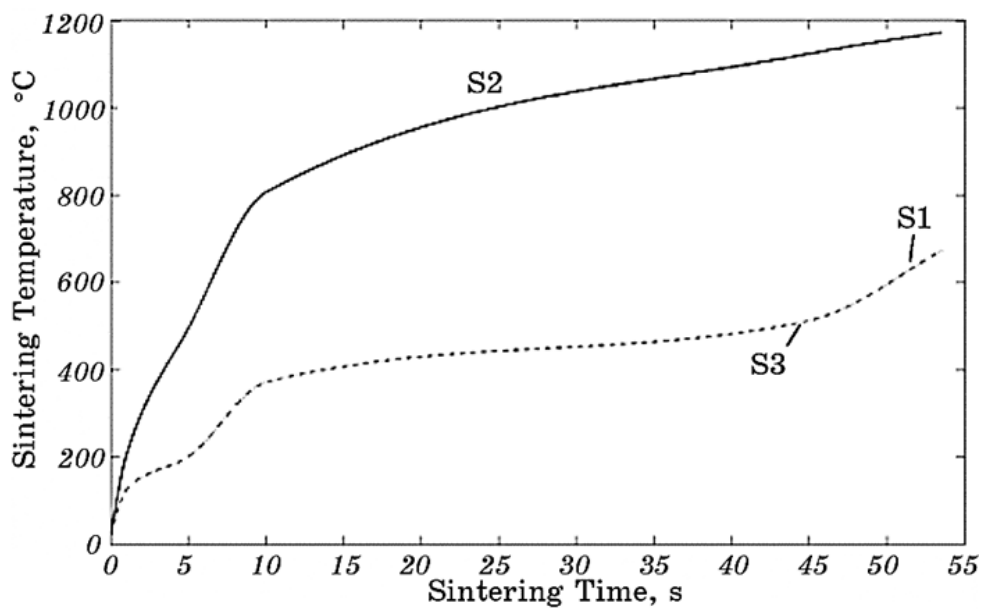

Fig. 9. Variation of sintering temperature with sintering time of surface temperature of S1, S2 and S3 iron-based PM compacts in ANSYS modelling. 
Çavdar and Atik studied medium frequency induction sintering of pure iron, 3 wt. $\%$ copper-mixed iron or 3 wt. $\%$ bronze-mixed iron [15]. Same $\mathrm{Fe}-\mathrm{Cu}$ composition as investigated in this study. Iron and iron-based powder metal compacts sintered at $1120^{\circ} \mathrm{C}$ by induction during 8.33 minutes are similar to those sintered conventionally in 30 minutes [15]. Mechanical properties are improved by the addition of copper or bronze powders to the iron matrix. Higher density, hardness and bending strain results were obtained from all induction sintered PM compacts compared to results from conventional sintered compacts. Experiment results illustrate that more ductile, dense and hard iron-based PM compacts can be produced by induction [15]. This study is a thermal analyses of medium frequency induction sintered $\mathrm{Fe}-\mathrm{Cu}$ compacts of the previous [15] study. This work illustrated that thermal and magnetic analyses could be calculated with ANSYS program for induction sintering of powder metal compacts. In addition, this study shows that all heating and sintering applications of bulk and powder metal compacts could be simulated using a program to examine the effects of magnetic flux and temperature distribution.

\section{CONCLUSIONS}

The following results were attained.

The penetration depth was $3.3 \mathrm{~mm}$ when we used an induction generator with a power of $1.2 \mathrm{~kW}$ and frequency of $30 \mathrm{kHz}$. Heat transfer produced by induction interaction heated the distance of $1.7 \mathrm{~mm}$ to the centre point of sample. PM compacts were heated to a sintering temperature of $1120^{\circ} \mathrm{C}$ in $53 \mathrm{~s}$ using the mentioned induction generator. Compacts were heated homogenously using this induction system. It was found by ANSYS analysis that the interaction of magnetic flux with the sample and the heat formed is affected by coil design and sample cross-section dimensions. According to ANSYS modelling of a sample with cross-section dimensions of $10 \times 10 \mathrm{~mm}^{2}$, it was found that the best design for wrapping coil for the interaction of magnetic flux with the sample is square shaped with inner edge of $32 \mathrm{~mm}$. ANSYS models were used for predictions of coil design, magnetic flux interaction, and sample shape, which decreases the need for extensive tiring experimental studies.

\section{REFERENCES}

1. R. M. German, Powder Metallurgy Science (Princeton, NJ: MPIF: 1984).

2. A. Salak, K. Vasilko, M. Selecka, and H. Danninger, J. Mater. Process. Technol., 176: 62 (2006).

4. I. Cristofolini, C. Menapace, M. Cazzolli, A. Rao, W. Pahl, and A. Molinari, J.Mater. Process. Technol., 212: 1513 (2012). 
5. M. R. Raza, F. Ahmad, M. A. Omar, and R. M. German, J. Mater. Process. Technol., 212: 164 (2012).

6. A. Kurt and H. Ateş, Materials and Design, 28: 230 (2007).

7. H. Arik and M. Turker, Materials and Design, 28: 140 (2007).

8. I. J. Shon, B. R. Kim, J. M. Doh, and J. K. Yoon, Ceram. Int., 36: 1797 (2010).

9. I. J. Shon, I. K. Jeong, J. H. Park, B. R. Kim, and K. T. Lee, Ceram. Int., 35, Iss. 1: 363 (2009).

10. T. Watanabe and T. Kohno, Report of the Casting Research Laboratory, No. 23: 1 (1972).

11. U. Çavdar and E. Atik, Modern Appl.Sci., 4, No. 3: 63 (2010).

12. U. Çavdar and E. Atik, Euro PM2009 Sintering (Copenhagen: 2009), p. 13.

13. U. Çavdar and E. Atik, 5-th International Powder Metallurgy Conference (Ankara: 2008), p. 18.

14. U. Çavdar (PhD Thesis) (2009), p. 110.

15. U. Çavdar and E. Atik, JOM, 66, No. 6: 1027 (2014).

16. V. K. Bobolev and L. G. Bolkhovitinov, Bulletin of the Academy of Sciences of the USSR, 709 (1960).

17. S. Zinn and S. L. Semiatin, ASM International, 3: 12 (1998).

18. J. Lewis, Engineering News, 43 (1999). 